\title{
A (NÃO) RELAÇÃO ENTRE TRADUTORES E COPIDESQUES NO PROCESSO DE EDIÇÃO DE OBRA EST RAN GEIRA ${ }^{1}$
}

\author{
Flávia C arneiro Anderson
}

\section{Introdução}

0 revisor tem de ser neutro pela natureza de seu trabalho. Se ele não conseguir manter neutralidade desde o início, não pode ser revisor. Eu, como tradutora, cobro respeito pela minha escolha de tradução.

(Regina M otta, tradutora)

A complexarelação autor-tradutor vem sendo exaustivamentediscutidapelos teóricos da tradução. Q uestionam-se, por um lado, as noções de autoria e de originalidade e, por outro, as de fidelidade e neutralidade tradutórias; discutem-se as questões da (in)visibilidade do tradutor e dos direitos autorais, além de inúmeros outros aspectos. Como resultado, pode-sedizer que, no quetangeàs questõesmais básicas, a relação autor-tradutor éalgo resolvido entre os estudiosos que acreditam que a tradução envolve transformação. Sob essa ótica, o autor não é visto como dono absoluto do texto eo tradutor, por sua vez, não étido como um mero copista, já que a tradução é concebida como uma reescrita. Entretanto, outras relações fundamentais no processo de edição do livro vêm sendo praticamente ignoradas pelos teóricos. Essas relações envolvem não só autores etradutores, como também editores, copidesques, revisores técnicos, revisores e preparadores, todos com possibilidade de exercer grande influência no trabalho do tradutor.

Como se sabe, o processo de edição de uma obra estrangeira traduzida tem início quando os editores escolhem os livros a serem publicados através do contato com agências e feiras literárias; em certas ocasiões, muito raras, aceitam a sugestão de leitores, autores sem agentes ou tradutores, desde que ela siga a linha adotada pela editora. U ma vez adquiridos os direitos autorais da obra, o editor ou o coordenador responsável por ela escolherá o tradutor com base em uma série de fatores: sua familiaridade com o assunto, qualificação, experiência, disponibilidade, remuneração etc. N essa fase inicial de produção o editor pode exigir que o tradutor adapte a obra a um determinado propósito de sua publicação na cultura-alvo. $\mathrm{N}$ a etapa seguinte, o copidesque, profissio- 
nal que costuma ter bastante autonomia para alterar e adequar o que julgar necessário, faz um cotejo do texto traduzido com o texto na língua-fonte. A pós esse trabalho, são feitas em geral mais duas revisões, as quais se concentram em erros de ortografia, sinais de pontuação e conferência de diagramação - nesses casos, sem o cotejo com o texto-fonte. 0 s revisores costumam ter menos autonomia do que os copidesques para intervir no texto (ver Linz, 2004: 156). D ependendo da obra, pode ser realizada também uma revisão técnica. 0 processo editorial envolve, portanto, toda uma seqüência de trabal hos no texto em que cada um vai retrabalhando o texto anterior.

M as ainda falta ao tradutor a consciência de que sua tradução só é sua atéo dia em que a entregou à editora. A edição de qualquer obra é um trabalho de equipe que se inicia antes da compra dos direitos de tradução e se prolonga por vários meses. 0 texto final representa o trabal ho dos vários profissionais, dos mais diversos níveis de cultura e enten dimento, que irão cotejar, compor e revisar a tradução sem que o seu autor volte a ser consultado. Para o tradutor profissional de ficção tal padrão só muda quando se trata de uma obra de ficção de grande projeção internacional, como um H arry Potter, por exemplo. (Wyler, 2003:196)

Como veremos no decorrer deste trabalho, os tradutores aos quais é dado o direito de examinar as revisões feitas em seu texto são verdadeiras exceções. Sejam consideradas positivas ou negativas, as interferências ocorridas no processo de edição do livro estrangeiro - sem o aval não só dos tradutores, como dos demais atores envolvidos - são práticas comuns no mundo editorial brasileiro, e como tal precisam ser levadas em conta. No que diz respeito ao tradutor, elas nem sempre são consideradas adequadas: "[Em] quase todas as revisões que meus trabal hos sofreram, houve a correção de uns três erros, e inclusão de mais doze, alguns realmente absurdos, que eu nunca teria feito" (Borten, tradutor). ${ }^{2}$ D a forma como o processo de edição de obra estrangeira traduzida é conduzido no Brasil, pode-se afirmar quea mai or parte dos tradutores não sabe o quanto foi modificado o seu texto até vêlo publicado.

0 presente trabalho, a ser aprofundado no futuro, visa justamente a colocar em primeiro plano uma das relações do processo editorial: a que ocorre entretradutor ecopidesque. N ossa proposta, pelo menos a princípio, éexaminála a partir das mesmas bases adotadas pelos teóricos da tradução para avaliar a relação autor-tradutor. Escolhemos a figura do copidesque porque, além do editor, é o profissional envolvido no processo editorial que mais parece ter chances de interferir nas escolhas do tradutor, pois julgará a tradução através 
deseu confronto com o texto-fonte: "H avia uma tradução queparecialáaos editores perfeita, eu fui checar palavra por palavra com o original, cortei muita coisa, fiz uma revisão, um copy desk violento nessas traduções" (Barroso, 1995: 36).

D ada a escassez de trabal hos sobre essa relação ea variação terminológica das profissões envolvidas no processo editorial, para os fins desteestudo vamos adotar as seguintes definições:

a. C opidesque - Aquele que se encarrega de fazer o cotejo da tradução com o original a fim de verificar eventuais erros de interpretação, redação, saltos etc. Ele busca também manter a consistência e 0 estilo, além de adequar o texto a glossários e linhas editoriais. (C abe acrescentar que o termo copidesque também pode designar o processo de revisão realizado por esse profissional, mas nesse caso optamos por utilizar a forma menos comum copidescagem.)

b. Revisor - Aquele que faz a avaliação somente da tradução, sem cotejo, sobretudo para verificar se o tradutor conseguiu adequá-la satisfatoriamente à língua-meta e para corrigir eventuais deslizes gramaticais.

c. Revisor técnico - Aquele que, na condição de especialista em áreas específicas do saber, avalia a pertinência e adequação dos termos e conceitos técnicos. d. Preparador - Aqueleque lida apenas com os elementos gráficos do texto. Em algumas editoras, no entanto, essetermo éutilizado como sinônimo de copidesque.

Essa confusão de nomenclatura fica muito clara nos depoimentos de tradutores e copidesques usados como base para o presente trabalho. Por esse motivo, à exceção das epígrafes, optamos por uniformizá-los adotando apenas os termos "copidesque" e "copidescagem", que aparecerão entre colchetes nas citações.

\section{Metodologia}

U ma vez escol hidos os profissionais que iríamos entrevistar, elaboramos dois questionários, um a ser enviado a tradutores e 0 outro, a copidesques, com o objetivo de averiguar o que cada um deles pensa não só a respeito do processo no qual eles próprios estão inseridos, como também da atividade do outro. 0 s questionários enviados são os seguintes:

\section{Tradutores:}

1. H á quanto tempo você exerce a profissão de tradutor?

2. Em sua opinião, qual seria o papel ideal do copidesque/revisor? 0 que de fato ocorre está muito distante desse ideal? 
3. Você acredita que o tradutor cobra do copidesque/revisor uma neutralidade impossível? A seu ver há uma luta pelo poder entre o tradutor e o copidesque/revisor? 4. U ma vez terminada a copidescagem/revisão de um trabalho seu, a editora Ihe permite opinar a respeito da mesma? Q uem escolhe a versão final, você ou o copidesque/revisor? H á quanto tempo isso ocorre?

5. Em sua opinião, a quem caberia a palavra final no tocante a textos traduzidos, ao tradutor ou ao copidesque/revisor?

6. Já teve al gum desentendimento com editores no que tange à copidescagem/ revisão de suas traduções? Em caso afirmativo, o que aconteceu?

7. Por favor, assinale a situação com a qual se identifica:

( ) N unca tive problemas com revisores

( ) Já tive problemas com revisores, mas atualmente não tenho mais

( ) Tive problemas com revisores em todas as traduções que realizei até o momento

( ) Tive problemas com revisores em 75\% das traduções que realizei atéo momento ( ) Tive problemas com revisores em $50 \%$ das traduções que realizei atéo momento ( ) Tive problemas com revisores em $25 \%$ das traduções que realizei atéo momento ( ) Tive problemas com revisores em $5 \%$ das traduções que realizei até o momento

Copidesques:

1. H á quanto tempo você exerce a profissão de copidesque/revisor?

2. Em sua opinião, qual seria o papel ideal do copidesque/revisor? 0 que de fato ocorre está muito distante desse ideal?

3. Vocêacredita que o tradutor cobra do copidesque/revisor uma neutralidade impossível? A seu ver há uma luta pelo poder entre o copidesque/revisor e 0 tradutor?

4. 0 seu trabalho de copidescagem/revisão é o último passo antes da publicação do livro? C aso não seja, costuma ter a oportunidade de opinar a respeito de possíveis modificações feitas em sua revisão? Considera que essas modificações podem ser realizadas sem 0 seu consentimento?

5. N a editora para a qual você trabal ha o texto traduzido costuma ser reenviado ao tradutor após passar pela copidescagem/revisão/revisão técnica?

6. 0 tradutor tem o direito de opinar a respeito da copidescagem/revisão? A quem você acha que deve caber a palavra final no tocante a textos traduzidos, ao tradutor ou ao copidesque/revisor?

7. Já teve al gum desentendimento com editores em função de um trabalho de copidescagem/revisão? Em caso afirmativo, o que aconteceu? 
8. Por favor, assinale a situação com a qual se identifica. Se já teve problemas com tradutores, poderia dar exemplos?

( ) N unca tive problemas com tradutores

( ) Já tive problemas com tradutores, mas atualmente não tenho mais

( ) Tive problemas com tradutores em todas as copidescagens que realizei até o momento

( ) Tive problemas com tradutores em $75 \%$ das copidescagens que realizei até o momento

( ) Tive problemas com tradutores em $50 \%$ das copidescagens que realizei até o momento

( ) Tive problemas com tradutores em $25 \%$ das copidescagens que realizei até o momento

( ) Tive problemas com tradutores em $5 \%$ das copidescagens que realizei até 0 momento

Essas perguntas foram enviadas por e-mail a 19 tradutores, dos quais 16 responderam, e a 17 copidesques, dos quais 13 responderam. Foram elaboradas tabelas nas quais agrupamos as diferentes respostas a cada pergunta. Ao final destetrabalho [ver Anexo] encontra-se a relação de todos os participantes da pesquisa. Julgamos importante ressaltar que $80 \%$ dos tradutores entrevistados trabalham há mais de dez anos nessa profissão, sendo que 43\% traduzem há mais de vinte anos. Sessenta por cento dos copidesques entrevistados exercem essa atividade há mais de dez anos, sendo que $23 \%$ fazem copidescagem há mais de vinte anos. Fica claro que tanto os tradutores como os copidesques entrevistados têm ampla experiência no mercado.

Julgamos ainda ser importante situar o universo desses entrevistados em meio aos demais universos com os quais lidaremos aqui. Em primeiro lugar, temos o universo dos estudiosos da tradução, e aqui nos referimos em especial aos que se identificam com o pensamento pós-moderno e que não vêem a tradução como uma simples reprodução de um texto estrangeiro na línguameta. Em segundo lugar, temos o universo do senso comum - aí incluídos 0 público em geral ea maior parte dos editores e tradutores sem formação teórica — , que crê na possibilidade da tradução como um texto absolutamente fiel ao original. Por fim, temos o universo dos tradutores literários que entrevistamos. M uito embora nem todos se situem no universo dos estudiosos da tradução, pode-se dizer que a maioria deles tem algum contato com o pensamento pósmoderno, o que os distancia das visões mais simplórias do senso comum.

Cabe também esclarecer que ao afirmarmos que vamos nos concentrar na relação tradutor-copidesque não entendemos que a palavra relação implica 
um encontro físico entre esses dois profissionais, tal como pareceu a alguns dos entrevistados. Temos consciência de que as editoras que promovem encontros entre tradutores e copidesques são exceções; entretanto, isso não significa que o vínculo imposto pelo processo de edição do livro não exista. Ao contrário do que tipicamente ocorre na relação tradutor-autor, tradutores e copidesques podem acompanhar as modificações feitas no texto traduzido, já que conhecem o seu idioma. M uito embora se possam citar autores que acompanham(ram) as traduções de suas obras - como éo caso do escritor alemão G ünter Grass, para quem o encontro regular com tradutores é não só uma garantia de qualidade para veiculação de suas obras, como também uma forma de relêlas de forma intensa (ver M ello, 2004), e do poliglota Guimarães Rosa, que se correspondeu com vários tradutores, em especial com Edoardo Bizzarri, que verteu para o italiano Corpo debaile - a grande maioria não chega a esse ponto, em função da própria barreira criada pelos idiomas estrangeiros. Como essa barreira não ocorre entre tradutores e copidesques, não é raro encontrar publicados depoimentos de tradutores revoltados com alterações que consideraram indevidas. Parece nos então pertinente questionar se o tradutor, apesar de inevitavelmente operar uma intervenção no texto que traduz, não exige do copidesque, contraditoriamente, uma neutralidade impossível. É o que procuraremos avaliar neste trabalho.

\section{Fundamentação teórica}

\section{III.1. A (in)existência da verdade absoluta}

Se, como queria Protágoras, as coisas não têm "medida" ou essência própria, se são aquilo que nos parecem ser, variando de acordo com as circunstâncias, então o que será isso a que chamamos a verdade? Sob esse ponto de vista, a verdade só pode resultar "de nossas opiniões sobre as coisas e do consenso que se forma em torno disso", sendo, portanto, "múltipla, relativa e mutável".

(H elena M artins, "Três caminhos na filosofia da linguagem")

D e acordo com M artins (2004), muitas das formas através das quais pensamos a linguagem correspondem à herança que nos foi deixada pel os gregos. 0 pensar filosófico nasceu como alternativa ao discurso mítico para a explicação das coisas. D esde muito cedo houve, nessa nova busca pela "verdade", uma polarização entre ossofistas, por um lado, e osfilósofos ditos socráticos, Sócrates, Platão e Aristóteles, por outro. Como os sofistas consideram que as coisas não possuem essência própria, a verdade é encarada como algo relativo; por outro lado, como os socráticos acreditam que as coisas têm uma essência permanente, então há nelas uma verdade única. 
Segundo Platão, a variação e a mutabilidade das coisas, tão enfatizadas pelos sofistas, seriam características do mundo das aparências; sob a superfície mutável e inconstante do real haveria um real de coisas invisíveis, perfeitas e eternas. E a linguagem, para escapar à variabilidade do real assim como é percebido pelos sentidos, só pode representar as formas essenciais (ver M artins, op. cit.). Portanto, de acordo com essa perspectiva universalista, as traduções podem ser absolutamente fiéis aos originais porque as línguas têm, apesar de sua aparente variabilidade, a mesma estrutura conceitual, um recorte semântico universal. Assim sendo, cabe ao tradutor buscar na língua-meta os correspondentes exatos para as palavras da língua-fonte. Se a sua tradução não é considerada boa, ou fiel, é porque ele não soube encontrar esses equivalentes perfeitos. 0 teórico G eorges M ounin critica essa postura, ressaltando que, de acordo com ela,

as dificul dades da tradução dependiam de fatos acidentais: ou o tradutor deixava de captar toda a substância do conteúdo de uma expressão da língua-fonte, transmitindo-a, conseqüentemente, de maneira incompleta; ou o tradutor conhecia de manei ra insuficiente os recursos das formas do conteúdo e das formas de expressão na língua-alvo e as utilizava inexatamente. Em ambos os casos, a falha da tradução constituía uma falha do tradutor. (M ounin, [1963]1975: 49)

O s relativistas, a exemplo dos sofistas, rompem com essa visão, afirmando que os povos recortam e organizam a reali idade de formas diferentes eque as línguas são, na verdade, sistemas de organização do mundo. O s significados já não são vistos como "coisas", reais ou mentais, pois correspondem somente aos usos culturalmente determinados que se fazem das palavras. A linguagem é entendida, sob esse ponto de vista, como uma práxis circunstanciada pela cultura, pela história e pelas idiossincrasias de cada ocasião (ver M artins, op. cit., p. 470). Como conseqüência desse modo de ver as línguas e os significados, a tradução passa a ser considerada impossível, uma vez que nas diferentes línguas o recorte da realidade não éigual: "N ão podemos traduzir porque nunca falamos exatamente da mesma coisa, mesmo quando falamos de um mesmo objeto, em duas línguas diferentes" (M ounin, op. cit., p. 58). 0 tradutor, por sua vez, passa a ser visto como um traidor porque nunca conseguirá reproduzir exatamenteo queo autor disse; daí o famoso adágio italiano: traduttoretraditore "Esta tese [o relativismo lingüístico] implica literalmente [...] a negação de qualquer possibilidade de tradução" (ibid, p. 55). Veja-se que por trás dessa crença na intraduzi bilidade decorrente da tese relativista subjaz aquele mesmo 
ideal de tradução como reprodução absolutamente fiel do original (ver Frota, 2000: 29-30).

O s estudiosos da tradução identificados com o pós-estruturalismo propõem então uma ruptura tanto com a concepção dos textos como receptáculos de conteúdos invariáveis em todas as línguas - caso da postura universalista - quanto com a de conteúdos que, embora variáveis entre as línguas, seriam homogêneos no interior de cada uma delas - caso da postura relativista. Sob essa nova perspectiva o tradutor faz uma leitura, interpreta o texto e produz significados, sempre sob a influência de seu contexto social e de traços subjetivos. A fidelidade do tradutor não está mais relacionada ao texto "original", ao "Autor", mas à sua interpretação do mesmo, que por sua vez dependerá daquilo que ele é, sente e pensa (ver Arrojo, [1986]2002: 44). Rompe-se, dessa forma, com as idéias da tradução seja como cópia ou como traição, pois, se não cabe ao tradutor reproduzir o texto de partida - o que de fato não é possível — , tampouco sedeve, a partir disso, considerar inviabilizada a tarefa tradutória. Trata-se de reconcebê-la como necessariamente uma transformação.

Como se pode situar a relação tradutor-copidesque à luz dessas teorias? $\mathrm{N}$ a já tão complexa relação autor-tradutor, o que ocorre quando entra em cena esse terceiro indivíduo? 0 ra, se as diferentes posturas que inspiram os tradutores irão influir nos modos como realizam suas práticas, estejam eles conscientes ou não dessa influência, o mesmo acontece com os copidesques. O bviamente, um copidesque que se alinha com a visão universalista de quea "tradução deve apresentar uma transcrição completa das idéias do trabalho original" (Tytler apud Frota, 2000: 28) será muito menos condescendente com as escolhas do tradutor e enxergará muito mais erros, ou infidelidades. Já que não crê na relatividade interpretativa, qual quer opção diferente da sua será tida como incorreta.

Para um copidesque que se afina com a postura relativista, diferentemente do que ocorre com aquele de tendência universalista, a cada língua corresponde uma visão de mundo específica. N o entanto, o problema nesse caso se repete, porque para esse copidesque as línguas e culturas são enxergadas cada qual como um bloco homogêneo, ainda que com recortes de mundo diferentesentresi. Como no interior de cadalíngua um determinado significante vem atrelado a um determinado significado, esse copidesque considerará que para cada palavra haverá sempre a mesma interpretação. É nesse sentido que 0 copidesque relativista, tal como o universalista, verá como equivocada uma interpretação diferente da sua (sobre essa reflexão ver Frota, 2000: 35-36).

Já um copidesque que se identifica com uma visão pós-estruturalista, por sua vez, na medida em que problematiza a leitura do original, consciente 
de que ao traduzir o tradutor transforma ou reconstrói o texto-fonte e de que as interpretações podem variar de um leitor para outro, tomará suas próprias interpretações como apenas alternativas possíveis às interpretações do tradutor e não verá motivo para alterar essas últimas. Ele só recorrerá a isso quando julgar que determinada interpretação do tradutor é de fato errada, ou seja, está fora de uma eventual gama de leituras diferentes, porém aceitáveis e justificáveis. No entanto, dadas as escolhas subjetivas características da tradução, fica difícil, mesmo nesse caso, haver um consenso em relação às alternativas mais adequadas:

É praticamente impossível para o tradutor despir-se detoda a sua experiência passada e conhecimento acumulado ao fazer uma tradução. Como conseqüência, ao executarmos um trabalho de tradução, aplicamos a esse trabalho o nosso próprio eu, a nossa ideologia, as nossas crenças e convicções. Assim, o que pode ser certo na minha visão pode ser totalmente incongruente na opinião de um outro colega. (França, 2003: 108)

Assim sendo, como julgar os momentos em que a intervenção do copidesque no texto traduzido é excessiva? A quem cabe esse julgamento? Isso nos remete a outros aspectos relevantes na relação tradutor-copidesque, que dizem respeito não só à forma como concebem o processo de tradução e revisão, como também a sua visão de "erro" e "acerto". É o que veremos a seguir.

\section{III.2. As teorias sobre leitura}

$\mathrm{N}$ a segunda tradução revisada pelo único editor/copidesque com quem tive contato[...] constatei que ele trocara os nomes de lugares geográficos [...] e as datas históricas [...], e escolhido termos que escapavam totalmenteao sentido do que estava escrito no original eà minhatradução, que estava correta.

(Renée Levié, tradutora)

Tradutores e copidesques são, antes de mais nada, leitores, e como tal assumirão diferentes posturas, conscientes ou não, diante de seus textos. Um modelo bastante predominante entre os anos 1930 e 1960, mas ainda muito popular hoje em dia - se não entre os teóricos, no senso comum - é o que encara a leitura como uma decodificação, um resgate das intenções e dos significados do autor. Sob essa ótica, o papel do leitor é tido como passivo, pois caberia a ele apenas extrair os significados que já estão dados no texto. É com 
base nesse modelo que se tecem comentários do tipo: "Aprecie-se ainda esta traição deslavada ao pensamento do autor" ou "Trata-se de uma tradução absolutamente infiel" (M oura, [1944]2003: 194, 208). O u seja, de acordo com essa visão de original e autoria,

a interferência do tradutor, por mais bem intencionada e apropriada que seja, será sempreo ato de um intruso mal visto, condenado à missão impossível de repetir os significados de outro sem tocá-los e sem marcá-los com seu próprio desejo autoral. Assim, defende-se a produção dos "originais" como atividade essencialmente criativa e, uma vez criado, qualquer texto deverá ser (e significar) apenas aquilo que seu Autor, seu amo e senhor, desejar. (Arrojo, 2003: 3)

Já em torno dos anos 1960/70 predominaram os modelos psicolingüísticos, que passaram a considerar a leitura como uma atividade puramente cognitiva. 0 papel do leitor recebe destaque, uma vez que esses modelos consideram queéna mente do leitor que são construídos os significados. No entanto, apesar de esses modelos ressaltarem as estratégias de leitura do leitor, pouca importância dão ao contexto no qual ele se insere. Isso só veio a acontecer no final dos anos 1970, com o surgimento dos modelos interativos que começaram a ver a leitura como uma atividade ao mesmo tempo cognitiva e social. Um dos maiores expoentes dessa linha teórica é Stanley Fish, para quem as interpretações do leitor dependem das estratégias e convenções de leitura da comunidade interpretativa à qual pertence. D essa forma, "os significados não são propriedades nem de textos fixos e estáveis nem de leitores livres e independentes, mas de comunidades interpretativas" (Fish, 1993: 156). N esse mesmo período, Roland Barthes declara a morte do Autor, que deixa de ser considerado fonte criativa única de sua obra, uma vez que sofre influência do seu contexto e dos inúmeros textos que leu.

Considerando-se que 0 autor nutre-se de outros autores no processo de criação, estamos diante da inexistência do autor enquanto criador de algo original e da impossibilidade da originalidade. A tradução é colocada, a meu ver, em posição semelhante à da autoria já que 0 autor, ao produzir uma obra, descreverásuatradução de outrastantas obras quejáleu. (Antunes, 2004: 105)

M as isso traz a lume paradoxos: se o autor está morto enquanto criador, por que o tradutor reivindicaria o prestígio da autoria? Segundo Frota, Barthes 
propôs uma redefinição de autoria que ajudou a desmistificar a excessiva sacralização dessa escrita; mas exterminar a autoria por inteiro e reivindicar para o tradutor, contraditoriamente, os atributos de um autor é um contra-senso.

Proponho questionarmos se não estará havendo, na esfera das teorias de tradução desenvolvidas a partir dos anos oitenta, um esgarçamento dos limites conceituais da tradução, a qual passou a ser identificada por muitos como uma reescrita manipuladora. Com esse relaxamento dos seus limites, a tradução parece estar sendo conceitual mente assimilada a outras formas de escrita, como a adaptação ou a própria escrita autoral, e assim perdendo as suas especificidades, incorporando formas de produção textual que fogem ao seu campo próprio. (Frota, 2004c: 1)

$\mathrm{N}$ ão restam dúvidas de que essas novas formas de encarar 0 ato de leitura contribuíram para destacar o papel ativo do tradutor. D e acordo com Fish, para que uma interpretação seja considerada adequada, ela precisa ser aceita pela comunidade interpretativa em que é formulada: se uma tradução é aceita por leitores de determinada comunidade, isso significa que ela está correta. D esconstroem-se as idéias de que o desejo e os significados do autor precisam ser protegidos a qualquer custo, e de que o tradutor deve ter uma escrita neutra. "É inevitável a interferência deelementos tais como crenças evalores no processo de compreen são, já queas convenções discursivasutilizadas refletem esses val ores e crenças, isto é, são determinadas socialmente" (D e Paula, Ilg, 2004: 47).

Isso nos levaria a concluir que, da mesma forma, o papel do copidesque tampouco pode ser passivo, uma vez que sua leitura sofrerá influência não só do contexto no qual ele se insere, como também de toda uma dimensão de subjetividade que vai além das intervenções de natureza estritamente sócioculturais (ver Frota, 2000: 18). N a próxima seção, falaremos brevemente sobre essa dimensão. N ão há como evitar, portanto, que o copidesque eventualmente faça uma leitura diferente da do tradutor e que realize alterações no texto vertido com base nessa interpretação divergente. A rigor isso inviabiliza a exigência por parte de tradutores de copidescagens neutras: " 0 [copidesque] demonstrou e documentou a própria insensi bilidade literária e bazófia nas intervenções, deturpando o pensamento do autor" (Barni, tradutora).

Se há hoje entre os tradutores um movimento crescente que rejeita a idéia da sua auto-anulação, como podem eles exigir que os copidesques se anulem? É óbvio que o copidesque, influenciado por seus próprios valores, contexto, leituras etc. interpretará o texto e fará as alterações que julgar necessárias. M uitas vezes procurará também, tal como o tradutor, adequá-lo à linha 
da editora. Q uando se trata de erros incontestáveis, conseqüência de saltos, ortografia incorreta etc., não há o que discutir. O corre que em tradução, dadas as infinitas opções por uma forma em detrimento de outra, muitas vezes não há um critério objetivo que realmente garanta que uma é certa e a outra é errada (ver Britto, 2003: 97).

\section{III.3. 0 "certo" e o "errado" na tradução}

Q uem poderia supor que $D$ eus se traduz por $D$ iabo? Pois a praga francesa nom de Dieu [...] verte-se otimamente para o nosso idioma, menos eufemístico, por "com os diabos".

(Paulo Rónai, Escola deTradutores)

$\mathrm{N}$ ão resta dúvida de que a revisão de textos traduzidos por uma terceira pessoa é imprescindível. Esse processo é essencial para a eliminação de alterações, omissões eacréscimos indevidamente cometidos pel os tradutores. Vários tradutores que participaram de nossa pesquisa mostraram-se inclusive gratos por correções que os salvaram de situações desagradáveis. O s erros de tradução não são incomunse, segundo Freud, podem ser inclusivemotivados por intervenção de desejos inconscientes. Esse tipo de erro, denominado "lapso de língua", não é causado por desatenção, mas pela imposição de um pensamento ou desejo inconsciente (ver Frota, 2004b: 6). 0 seguinte exemplo, dado por Freud, deixa claro o que ocorre quando se dá esse lapso: ao passar uma receita, um médico escreveu Ethyl ("álcool etílico") em lugar de Ethel, nome da paciente em questão, a qual "costumava beber mais do que Ihe convinha" (Apud Frota, 2004b: 8). Seja qual for o motivo da ocorrência de erros no texto traduzido, fica a critério do copidesque analisá-los e corrigi-los. Parece-nos que as retificações de copidesques questionadas por tradutores são justamente aquelas que não envolvem o que propriamente se deve considerar um erro.

0 teórico Anthony Pym faz a distinção entre o erro binário, que ele chama de mistake, e o erro não-binário, que ele denomina de error. 0 erro binário envolve uma escolha clara entre uma possi bilidade correta e outra errada; não há espaço para nuanças ou gradações. 0 erro não-binário é justamente o oposto: não há uma separação clara entre o certo e o errado. 0 exemplo de Pym é claro: traduzir five million por "cinco mil" é erro binário; já thebush pode ser traduzido como "o monte" e inúmeras alternativas também (Pym apud Frota, 2004b: 2). Frota chama a atenção para o fato de quePym, ao entender todas as nuanças fora do pólo binário como errors, acaba desconsiderando as variações subjetivas nos 
julgamentos relativosa tal escolha. Ela propõeque, além das noções dicotômicas de certo e errado, atribuíveis àquelas escol has que na avaliação de um grupo não dão margem a questionamento ou discussão, se passe a trabalhar também com uma terceira noção, intermediária e não-binária, onde se situariam as diferentes preferências subjetivas.

N o processo tradutório, o tradutor está constantemente escolhendo palavras, frases e efeitos em detrimento de outros. É em função dessas preferências subjetivas que nunca se pode afirmar, excetuando situações onde ocorram erros tidos consensualmente em determinada comunidade como binários, que determinada escolha é a única correta. 0 processo de copidescagem é um momento delicado justamente porque pode ser realizado com base apenas em uma lógica dicotômica do certo e errado; se isso ocorre, o copidesque pode considerar "erradas" as opções do tradutor simplesmente por diferirem das suas. Por esse motivo, um copidesque que se al inhe com a postura universalista pode considerar incorreta a tradução de "H e [the father] kissed his daughter on the mouth" por "Ele deu um forte abraço na filha" (ver Santana, 2002). Já um copidesque que se afine com a visão pós-estruturalista da linguagem podeconsiderar que o tradutor procurou aproximar a tradução do contexto da línguameta, uma vez que no Brasil os pais não costumam beijar as filhas na boca. É justamente quando atua no âmbito dessas preferências subjetivas, e não no âmbito dos erros binários, que o processo de copidescagem parece suscitar maior controvérsia. São inúmeros os exemplos de intervenções consideradas inadequadas pel os tradutores entrevistados neste trabal ho:

a) "O [copidesque] não resiste e muda trechos e termos, achando que 'fica melhor assim'" (Q uental, tradutora).

b) 0 [copidesque] havia feito dezenas de substituições tolas (a troca do seis pelo meia-dúzia), acrescentado erros que não existiam" (Grillo, tradutor).

c) "Já tive problemas, quando o [copidesque] quis mostrar trabalho e mudou coisas desnecessárias. Por exemplo: mudou 'via' por 'por meio de' num texto com espaço limitado" (M otta, tradutora).

d) "N em todas as minhas traduções são revistas, pelo menos do meu conhecimento. As que eu recebo o retorno do [copidesque], o normal é ter três erros corrigidos, doze erros acrescentados, e uma série dealterações inócuas, questão de estilo" (Borten, tradutor).

$\mathrm{H}$ á inclusive depoimentos bem-humorados sobre a interferência do copidesque: 
Tive um desentendimento certa vez com uma [copidesque] que cismava em corrigir umas bobagens nas traduções que eu fazia em uma editora. Daí um dia fui olhar a revista médica recém-chegada da impressão e estava lá, logo no começo do artigo, o tal "Via de regra". Gente, eu odeio "Via de regra". [...] N unca, nunquinha, nem sob tortura eu começo um parágrafo com "Via de regra". D aí a moça ficou chateada quando eu pedi e-d-u-c-a-d-a-m-en-t-e que ela não fizesse mais essa alteração nos meus textos. Pronto! Q uase todos os meses ela cismava de tacar o tal "VDR" nos meus textos. $\mathrm{H}$ avia um certo prazer naquilo, eu podia sentir delonge. [...] Tudo bem: passei a trocar o nome da revisora. Chamei-a de Varélia (aka Valéria) durante muito tempo. Sei lá, gostei...Varélia era muito mais legal. (N ascimento, tradutora)

Como à maioria dos tradutores entrevistados não é dada a oportunidade de opinar sobre as revisões feitas em suas traduções, eles se sentem revoltados ou frustrados com as modificações que consi deram inadequadas ou desnecessárias: daí as constantes queixas, encontradas não só nos depoimentos dos tradutores entrevistados para este trabalho, como também em publicações de naturezas diversas (ver, por exemplo, Benedetti \& Sobral, 2003 e site tradport). Vários tradutores chegam ao ponto de evitar ler suas obras publicadas ou de usar pseudônimos para evitar aborrecimentos.

\section{0 papel ideal do copidesque}

Já vi horrores incríveis serem praticados pela revisão, sem nenhum respeito pelo trabalho realizado pelo colega.

(Erik Borten, tradutor)

N unca tive problemas com nenhum tradutor; porém, muitas traduções malfeitas já me deram bastante trabalho, talvez 50\% delas, no mínimo. (Teresa da Rocha, copidesque)

Em linhas gerais, deacordo com os tradutores entrevistados, o copidesque deveria "corrigir erros gramaticais e possíveis 'cochilos' do tradutor, [além de] verificar adequação de registro e vocabulário utilizados", "zelar pela qualidade do texto e respeitar a escolha do tradutor", padronizar o texto "conforme a linha daquela editora específica" e apontar e propor "soluções outras para tre chos que considere 'complicados' em diversos sentidos". Q uarenta e quatro por cento dos tradutores, no entanto, disseram que o copidesque acaba extrapolando suas "funções", tornando-se um "censor gramatical", "deturpando o trabalho do tradutor", fazendo "substituições tolas", "mudando trechose termos, achando que 'fica melhor assim'", "traduzindo de novo", "editando", "arrogando-se funções quenão Ihe[cabem]", "intervindo mais do que o neces- 
sário". Tal como sugerimosna introdução do presente trabalho, apesar de muitos tradutores virem lutando para desconstruir a idéia vigente no senso comum de que são meros copistas, ressaltando a inevitabilidade de sua intervenção no texto-fonte, parecem recusar-se a aceitar que o copidesque, por sua vez, intervenha no texto traduzido. M esmo que quisesse, seria possível para o copidesque anular sua própria interpretação do texto, além de todo o contexto no qual se insere, a fim de ir sempre ao encontro das decisões e desejos do tradutor?

Se a situação está longe do ideal, isso se deve [...] a uma falta de iniciativa, por parte dos tradutores, no sentido deaceitarem a revisão como uma leitura responsável e indispensável e de discutirem as alterações a serem feitas sem a vai dade que marca a atitude ingênua daquele queacredita que o texto é só seu. (Azenha, tradutor)

Em todas as esferas nas quais vários profissionais trabalham juntos e se lida com escolhas subjetivas há possibilidade de tensão. A dubladora e tradutora Dilma $M$ achado se ressentiu recentemente com um diretor que para a frase I'm not proud to do this preferiu mudar o que ela havia escrito, "N ão sinto orgulho de fazer isso", para a tradução incorreta "N ão tenho vergonha de fazer isso". N esse caso, não só essa, mas todas as inúmeras modificações feitas pelo diretor no momento da dublagem é que vão valer, a despeito da opinião da tradutora.

N o campo da interpretação de um modo geral, éóbvio que as opiniões vão divergir. Um outro exemplo disso é o pedido de demissão de um famoso diretor deuma novela, feito há pouco tempo. Em um artigo no jornal 0 Globo (Kogut, 2005: 16), a autora, Glória Peres, explicou: "recentemente passamos a ter idéias diferentes sobre a condução da tramae seus personagens, criando um descompasso". N a sinopse da novela a heroína, Sol, é descrita como "corajosa, vital, al egre e [al guém que] não chora". N a interpretação do diretor, no entanto, Sol se mostra triste e chora com freqüência. A autora simplesmente não admitiu uma interpretação diferente da sua para a personagem que criou. Interpretações diferentes sobre a forma de conduzir determinados personagens de romances podem ocorrer também entre tradutores e copidesques. Ao traduzir uma obra literária de época, a tradutora Sonia M oreira foi convidada a opinar sobre um "alerta" feito pela copidesque:

nesse alerta, ela dizia que estava na dúvida se o vocabulário que eu havia empregado nas falas de um determinado personagem não seria "moderno" demais para a época em que o conto fora escrito. (Ela fez o alerta, mas não chegou a mexer nas tais "fal as modernas" do personagem; ou seja, não che- 
gou a dar outras soluções. 0 personagem era um americano bastantecaricato etinha um modo de falar aparentemente "exótico", em comparação com o dos outros personagens [europeus] do conto). (M oreira, tradutora)

U ma alternativa possível para aliviar as tensões geradas pela inevitável interferência do copidesque no texto traduzido seria levar a cabo o que 44\% dos tradutores sugeriram: que houvesse al gum tipo de interação entre tradutores e copidesques. Em outras palavras, que o tradutor tivesse a chance de opinar sobre as modificações feitas em seu texto. A pesar de alguns tradutores terem mencionado que muitas editoras evitam fazer isso al egando que tal procedimento atrasaria a publicação da obra, isso não tem impedido que a copidescagem da tradução seja enviada a al guns tradutores experientes eàqueles que exigem que isso seja feito. A tradutora Roberta Barni sugere que "quando a editora percebe que o tradutor é seguro do que faz, sabe trabalhar e exige rever o trabalho, ela mesma orienta o [copidesque] para 'não interferir demais no texto', a não ser que seja necessário ou que se tenha uma idéia brilhante a propor". Caberia então aos tradutores impor suas condições e exigir rever o trabal ho? U ma mudança no processo de edição de obra estrangei ra que permitisse um "diálogo" entre tradutor e copidesque certamente iria ao encontro do que solicitam os tradutores. Resta saber se as editoras estariam dispostas a modificar o costume já arraigado de alterar o texto traduzido sem a autorização do tradutor.

Pode-se confirmar a existência de relações de poder eo tratamento diferenciado mencionado indiretamente por Barni através do depoimento do copidesque, tradutor e editor AndréTelles, para quem o "cuidado com os possíveis melindres do autor" brasileiro é maior do que com os do tradutor. No decorrer da produção editorial, o cuidado tomado com o queTelles denomina de "melindres" não só parece variar de tradutor para tradutor - já que a algunsédado o direito de rever a copidescagem de suas traduções; copidescagem essa que inclusive pode ter sido feita, a pedido do editor, com o objetivo de interferir menos - como também parece ser diferenciado no caso de tradutores e autores. Segundo Telles, os "livros brasil lei ros sempre voltam ao autor para sua aprovação".

O s copidesques, por sua vez, no que diz respeito a seus papéis, disseram que devem: realizar "correções ortográficas e sintáticas [e indicar] discrepâncias internas e despadronizações"; "manter a consistência e estilo [...] e observar o respeito aos glossários"; "indicar a necessidade de 'ajustes' na tradução [e] aprimorar a redação do texto"; "apontar problemas (desvios da norma culta, 
quando o texto não os comporta; gral has; saltos; redação truncada, entre outros) e propor soluções"; "dar um parecer sobre as escol has do tradutor e corrigir erros"; "lapidar o texto". M as enquanto 44\% dos tradutores criticaram a atuação do copidesque, apenas $23 \%$ dos copidesques criticaram a atuação do tradutor. N esse caso, os copidesques al egaram que os tradutores tendem a se afastar da língua-meta e que muitas vezes eles são obrigados a refazer o trabaIho, em virtude de traduções de má qualidade. Curiosamente, apenas uma copidesque, que por sinal é também tradutora, mencionou que deveria haver integração entre o trabalho do tradutor e o do copidesque. Com esse resultado, vê-se novamente a diferença de opinião entre tradutores e copidesques no que tange aos tais "ajustes" ou "lapidagens" na tradução; no âmbito das escoIhas subjetivas, muitos "ajustes" considerados ad equados pel os copidesques são tidos como interferências indesejáveis pelos tradutores.

\section{A cobrança de neutralidade e a luta pelo poder}

0 preparador simplesmente delirou, achou que sabia mais da línguafonte do queeu, achou que sabia escrever melhor do que o autor, enfim, um desastre, interveio pesadamente no texto e até introduziu erros. (Roberta Barni, tradutora)

$\mathrm{H}$ átradutores deníveis muito diferentes. Alguns são muito bons, ecom esses se apren de muito; outros nem tanto, às vezes nos obrigando a praticamente refazer o trabalho de tradução.

(Sofia Silva, copidesque)

Q uando indagados se consideravam que os tradutores cobravam dos copidesques uma neutralidade impossível, dois pontos muito citados pelos entrevistados foram, por um lado, que haveria por parte dos copidesques a necessidade de "mostrar serviço" e, por outro, que é o tradutor quem leva a culpa na mídia quando há erros na obra publicada. No que tange ao primeiro ponto levantado - a necessidade de "mostrar serviço" - , para $12 \%$ dos tradutores entrevistados não só os tradutores, como os demais participantes da produção de obra estrangeira sentem necessidade de "aparecer": "N ão vejo luta pelo poder, mas eventualmente tradutores e [copidesques] mal formadose mal remunerados, sequiosos de mostrar serviço e provar a sua própria importância, às vezes aos seus próprios olhos" (Aguiar, tradutor). Para outros 12\%, 0 copidesque quer mostrar serviço porque "a impressão que setem, sem marcas no texto, é a de que ele não trabalhou. [...] É uma luta pela visibilidade, na qual é fácil incorrer; mas isso acontece [...] por falta do editor" (Barni, tradutora). 
Com relação ao segundo ponto levantado - o tradutor é quem leva a culpa na mídia - , 31\% dos entrevistados disseram que, apesar de o costume vigenteno processo editorial de obra estrangeira no Brasil ser o da não interação entre tradutores e copidesques, e o das modificações feitas à revelia do tradutor, quem figura publicamentecomo responsável pelo texto-meta éo tradutor:

\begin{abstract}
Já tive a experiência de ver uma página de tradução minha praticamente desfigurada por um [copidesque]. N ão se trata de uma luta pelo poder, porque o tradutor vende os direitos para a editora, ea partir desse momento a editora pode fazer o que quiser do texto. Só acho que se é para mudar completamente o texto do tradutor fica meio engraçado colocar o nome do tradutor na folha de rosto. (Falck, tradutora)
\end{abstract}

E isso nos remete ao terceiro ponto levantado pelos tradutores. Tal como já foi sugerido na seção IV deste trabalho, os entrevistados ressaltaram a necessidade de haver "contato estreito" e "interação" entre tradutores e copidesques. Vários tradutores afirmaram que muitas vezes a escolha do copidesque pode ser melhor, não havendo, portanto, "nenhum empecilho [...] em aceitar o termo sugerido pelo [copidesque], desde que dentro de um diálogo e uma troca deidéiase, principal mente, um sólido embasamento gramatical, terminológico ecultural quejustifique ou não o termo apresentado pelo [copidesque]" (Levié, tradutora). Q uando o tradutor sabe que quaisquer modificações no texto-meta passarão pelo seu próprio crivo, parece diminuir ou cessar a cobrança de neutralidade: "eu não cobro neutralidade do [copidesque]; apenas peço que todas as decisões dele passem por mim antes de o livro ir para a gráfica" (Britto, tradutor).

Para que esse diálogo ocorra, o tradutor não teria que cobrar dos copidesques "mas sim dos editores, eles sim responsáveis finais por eventuais aberrações produzidas pela interação tradução/[copidescagem]" (Aguiar, tradutor). Para alguns entrevistados, a luta pelo poder, ou pela visibilidade, ocorre justamentequando "não há clareza nos papéis a serem desempenhados. [Portanto] 0 coordenador do projeto e/ou editor e/ou intermediador devem procurar estabelecer uma relação de interação entre o tradutor e o [copidesque]" (M otta, tradutora). 0 diálogo entre tradutores e copidesques é produtivo porque o tradutor pode ter uma idéia dos pontos a melhorar, dos termos corretos a usar, 0 que permite que haja um aprendizado constante (N ascimento, tradutora).

Em contraste com o quefoi dito pelos tradutores, a necessidade de "aparecer" só foi mencionada por um copidesque, para quem "há tradutores que gostam de chamar atenção para o seu texto, muitas vezes tentando 'melhorar' 
o original" (Telles, copidesque, tradutor e editor). D a mesma forma, só uma copidesque trouxe à tona o fato de o tradutor assinar a tradução: "N a maior parte das vezes nem chego a ter contato com os tradutores dos livros que reviso. $\mathrm{M}$ as, pessoalmente, acredito que um tradutor competente é quem deve dar a palavra final sobrea tradução. É ele quem a assina" (Silva, copidesque). Por sinal, $41 \%$ dos copidesques afirmaram não ter tido contato direto com tradutores e apenas a copidesque que também é tradutora levantou a questão da falta de diálogo: "o problema é que muitas vezes não há qualquer diálogo. D epois de entregar seu trabalho, o tradutor só volta a ver o texto depois de publicado. 0 que é grave e não devia ser dessa forma" (Senna, copidesque e tradutora).

0 editor citado como responsável por um processo que não é o ideal também foi mencionado por Senna: "não acho que o problema seja entre [copidesque] e tradutor, mas entre editor e tradutor. 0 [copidesque] pode apontar problemas, mas normalmente é o editor quem decide mexer ou não em um texto".

\section{A avaliação da copidescagem e a escolha da versão final}

São raras, raríssimas, as editoras quesequer propõem apresentar aostradutores as revisões feitas. 0 corre, mas éraro, ejá vi dar briga. Contudo, quando proponho ou me propõem obras que considero importantes, eu exijo a palavra final. Se quiserem revisar trinta vezes, que o façam, mas o editor terá de devolver para eu aprovar no final. 0 visto bom é meu, que assino.

(Renato Aguiar, tradutor)

Q uando escolhemos o tema destetrabal ho, supúnhamos queapenas aos tradutores iniciantes não era dada a oportunidade de opinar sobre a copidescagem feita em suas traduções; ou seja, em virtude de sua pouca experiência, as editoras evitariam reenviar-Ihes a tradução copidescada. Essa hipótese foi descartada, uma vez que $80 \%$ dos tradutores entrevistados já exercem a profissão há mais de dez anose, no entanto, $60 \%$ tampouco recebem de volta o texto copidescado. Esse número foi confirmado pelos copidesques entrevistados, dos quais 60\% afirmaram que nas editoras para as quais trabal ham o texto traduzido não costuma ser reenviado ao tradutor. Insatisfeitos com essa situação, alguns tradutores afirmam ter deixado de trabalhar para as editoras quenão Ihes permitem rever a copidescagem: "H á al gumas [editoras...] para as quais não mais trabal ho por causa da 'ditadura gramaticalesca'" (Sobral, tradutor); " $\mathrm{H}$ á umas duas editoras com as quais não consegui [rever a copidescagem ...]; nesses casos, deixei de trabalhar para elas" (Barni, tradutora). O utros 
tradutores afirmaram que para evitar aborrecimentos não lêem o texto-meta publicado, ou recorrem ao uso de pseudônimo:

Q uando tive problema com a [editora $\left.{ }^{3} . ..\right]$, consegui [...] que ela me encaminhasse o livro depois de revisado, para eu dar uma última olhada. C heguei a fazer isso com um livro e foi um sofrimento ver meu texto completamente alterado. D ecidi optar pelo uso de um pseudônimo nessa editora especificamente, e eles aceitaram. (G rillo, tradutor)

Apesar das inúmeras queixas por parte dos tradutores no que tange à copidescagem, revêla implica um trabalho adicional, muitas vezes não-remunerado, que deve ser levado em conta: "Já me ocorreu reivindicar essa releitura, que me foi concedida mas de que contudo me arrependi, porque (1) o trabalho adicional que isto representou não acrescentou nem um tostão à remuneração a que eu já fizera direito" (Flaksman, tradutor). C omo essa tarefa pode ser monumental no caso de livros extensos, ela poderia explicar, talvez, a aparente inexistência de uma pressão maior por parte dos tradutores para real izá-la. Para o tradutor Sérgio Flaksman, a falta da compensação financeira para esse trabal ho extra seria "um dos mecanismos viciados a alimentar a perpetuação de profundas deformações nesta área. E mais ainda quando o trabal ho ainda se sujeita, ao fim e ao cabo detoda esta releitura, a mais um número indeterminado de 'revisões'. Situações similares ocorreram com a tradutora Roberta Barni. Em uma delas, o editor "foi obrigado a admitir que eu estava certa. Resultado: pagou-me, e bem, para que eu arrumasse de volta o texto". N a outra, entretanto,

o editor [...] reconheceu quea [copidescagem] estava desastrosa, edisse que simplesmente não chamaria mais aquele [copidesque], mas não foi além disso, e deixou a bomba na minha mão. Por uma questão de delicadeza para com 0 autor que até tinha me indicado, tornei a arrumar tudo, mas muito a contragosto, um trabalhão danado, sem receber para isso! (Barni, tradutora)

Já vimos que, no que concerneà copidescagem, as editoras parecem dar um tratamento diferenciado a tradutores e autores. Será que isso ocorre porque o custo e o tempo de edição da obra nacional, sem a participação de tradutores e copidesques, émuito menor? 0 u será que a não-revisão da copidescagem por parte dos tradutores é simplesmente uma praxe que pode ser alterada, faltando para tanto que os tradutores se mobilizem? D e acordo com a editora D aniele Cajueiro, ${ }^{4}$ a N ova Fronteira, por exemplo, costuma enviar a copidescagem ao tradutor. Já segundo a editora Silvia Leitão, ${ }^{5}$ a Record não 
tem essa prática. $\mathrm{N}$ a editora para a qual trabalha AndréTelles, isso tampouco costuma ser feito:

N a maior parte dos casos o texto não volta ao tradutor (seria arranjar sarna para se coçar...). Além disso, como os tradutores são mais ou menos fixos e trabal ham há anos para a editora, devem ficar "resignados" ou "gratos". U m comentário de um editor conhecido: "N ão se pode contratar um tradutor porque se viu o nome dele numa boa tradução. A gente contrata ele, e depois vê que o trabalho todo tinha sido do copy e da editora". (Telles, editor, tradutor, copidesque)

Faltaria ao tradutor essa "resignação" ou "gratidão"? A "resignação" de assinar uma tradução com alterações de copidescagem que podem comprometer, ou não, o seu trabalho, uma vez que o processo editorial é, na verdade, uma linha de produção? "Um termo que me custou muita pesquisa foi substituído pelo revisor por um falso cognato que tornava toda a passagem absurda. Briguei muito com a editora, ea partir daí el es passaram a ficar mais cuidadosos com os meus textos" (Britto, tradutor). A "gratidão" por participar de uma linha de produção na qual tanto podem atuar profissionais competentes como incompetentes, que, se por um lado podem melhorar muito o texto-meta, por outro, podem piorá-lo? 0 u estaria faltando ao tradutor a consciência de que

todos que trabalham na produção editorial precisam ter noção de que um texto não é um filho. $E$, mesmo se for, o filho não é só seu. Essa idéia do "esse texto é meu e ninguém mete o bedelho" pode ter sentido em alguns contextosespecíficos, como trabal hos literáriosou acadêmicos. M as, na maior parte da produção textual de hoje (manuais, relatórios, livros didáticos, livros de referência etc.), o que temos é um trabalho em equipe, no qual as disputas pelo poder não fazem sentido. (Guimarães, copidesque)

No que diz respeito aos copidesques, $75 \%$ afirmaram não ter acesso às modificações feitas posteriormente em seu próprio trabal ho de copidescagem; ou seja, disseram não saber se suas modificações foram incorporadas ou não ao texto-meta. Trinta por cento deles disseram que gostariam de ter a chance de opinar sobre essas modificações, mas que entendiam que isso não ocorria em função do processo editorial: "É claro que eu gostaria de ser consultada sobre as modificações feitas após meu trabalho, mas, por ter trabalhado como coordenador editorial, sei que isso é bem complicado e muitas vezes inviável" (C anetti, copidesque); "É incômodo pensar que seu trabalho talvez seja tratado de forma pouco ética, mas não posso ocupar um espaço que não é meu - eu não dou a 
palavra final na publicação, preciso confiar nos meus colegas" (Rodrigues, copidesque); "É sempre bom mostrar ao revisor [as modificações que foram feitas posteriormente ao seu trabalho]" (Bellinelo, copidesque); "Já me aconteceu de ver um livro publicado e ver que muitas das minhas emendas não foram incorporadas. Imaginei que foram imposições do tradutor. Às vezes, não posso deixar de lamentar, mas sei que são essas as regras do jogo" (Silva, copidesque).

Já outros copidesques, tal qual Thelma Guimarães, acham que não cabem ao copidesque as decisões finais: "Penso no cliente ese para ele for melhor alterar o quejá alterei, por que não? Como disse, penso em um trabal ho complementar, em equipe" (Santos, copidesque); “D epois que o [copidesque] entrega o trabalho, cabe à editora decidir acatar ou não as emendas sugeridas, uma vez que é dela a responsabilidade pela publicação do livro" (Rocha, copidesque); "o trabalho de [copidescagem] não é autoral, por isso não vejo motivo de o editor ter de dar satisfação do que vai manter ou não das marcações do [copidesque]" (Senna, copidesque e tradutora).

Sendo a intenção de todo processo derevisão de obra estrangeira traduzida chegar a um produto final de qualidade, estaria faltando ao tradutor essa visão de trabalho em grupo, de um processo que envolve indivíduos e etapas diferentes? Seria a melhor opção do tradutor "aceitar as regras do jogo", "confiar em seus colegas" e acatar as escolhas dos copidesques e editores? O u seria a tradução, de fato, algo "pessoal eintransferível"?

Nunca deixei de pensar que uma vez feita por mim a tradução, está ela pronta. $\mathrm{N}$ ão se trata de pretensão. Estou apenas querendo dizer que uma nova tradução do mesmo texto é, digamos assim, uma outra obra. Algo como uma coisa pessoal e intran sferível. (Gonçalves, 2003: 112)

Q uando questionados a respeito de a quem deveria caber a palavra final no tocante a textos traduzidos, $50 \%$ dos tradutores afirmaram que ela caberia ao tradutor. $\mathrm{N}$ a opinião de $6 \%$ dos tradutores participantes, caberia ao editor dar a palavra final; para outros $6 \%$ a versão final, no caso de textos técnicos, deveria ficar a cargo do revisor técnico. Já para 30\% dos participantes, deveria haver um trabalho conjunto:

Colocada como está, a pergunta induz, a meu ver, à retroalimentação de um processo compartimentado. A rigor - e se quisermos ser coerentes com as contribuições dos Estudos da Tradução dosúltimos vinte anos - a última palavra não éa última e não deve ser dada a um só. Só que para fazer isso valer no meio não acadêmico, o tradutor precisa sevaler de argumentos 
não acadêmicos. Assim, épreciso convencer o outro deque o trabalho conjunto reduz os riscos do insucesso, o que podesignificar garantia de retorno de investimento. (Azenha, tradutor)

Sob o ponto de vista do tradutor João Azenha, os tradutores não devem exigir a palavra final sobre seus trabalhos, mas sem dúvida alguma terão de requerer o retorno do texto copidescado para que possam debater as mudanças das quais discordam; de outra forma, seria impossível a efetivação do que ele chama de "trabal ho conjunto". Já para a tradutora Renée L evié, "a tradução é de propriedade(criação) do/a tradutor/a, e nenhuma modificação deveria ser feita sem a sua aprovação prévia". D a mesma forma pensam a tradutora Roberta Barni, para quem o tradutor deve ter a última palavra porque é ele "quem assina a tradução" e a tradutora e copidesque Janaína Senna, para quem o trabalho do tradutor é "um trabalho autoral. 0 tradutor éo responsável, digamos assim, por aquela obra, e não o [copidesque]."

A opinião dos copidesques parece se alinhar com a de Azenha. A pesar de $54 \%$ dos copidesques terem afirmado que o tradutor deveria ter o direito de opinar sobre a copidescagem, apenas $20 \%$ consideraram que a palavra final deveria ser do tradutor. Para a maioria, $46 \%$, a palavra final cabe ao editor: "0 cliente é quem tem o poder de decidir o que ele acha que venderá, o que ele considera que agrada seu público e o preciosismo, por vezes, é um ideal que aprendemos em sala de aula mas que na prática, em al gumas situações, não se aplica" (Santos, copidesque).

\section{D esentendimentos entre tradutores, copidesques e editores}

0 editor, exigindo um texto elegante, "bem escrito", de fácil leitura, impôs modificações que o tradutor, fiel ao estilo estranho, áspero, de seu autor, recusou-se a aceitar. Seguiram-se acusações, aborrecimentos, humilhações (para o tradutor, é claro, porque no par tradutor-editor 0 primeiro sempre éo mais fraco).

(Pierre Blanchaud, apud Kundera, 1996)

Q uando perguntados se já teriam tido algum tipo de problema com editores, seja no que tange à copidescagem ou a outros aspectos, $62 \%$ dos tradutores disseram que sim, 0 que demonstra 0 alto grau de insatisfação dos tradutores com o processo editorial. Alguns se queixaram de divergências no que tange à remuneração; a maioria, no entanto, citou, mais uma vez, alterações na etapa de copidescagem do texto traduzido que consideraram inadequadas: "dois livros de épocas totalmente distintas ficaram iguaizinhos, o que 
a meu ver é um erro" (Sobral, tradutor); "já saiu tradução minha com erro cometido pelo [copidesque], mas aí o assunto foi resolvido entre a supervisão e o [copidesque]" (N ascimento, tradutora); "eu só protestei dizendo que tinham mexido muito na [copidescagem...], mas a tradução já estava publicada e o que fazer? Aliás, se eu assino um contrato de cessão de direitos, estou alienando minha obra, portanto a editora pode fazer o que quiser do texto. Se eu não assinar o contrato, ela não me dá trabalho" (Falck, tradutora).

Tal como ressaltou a tradutora C elina Falck, ao entregar uma obra traduzida à editora, o tradutor é de fato obrigado a assinar um contrato de cessão de direitos autorais de tradução que inclui até seus herdeiros e sucessores. Por intermédio dele, o tradutor "cede etranffereà [editora], em caráter definitivo, a totalidade de seus direitos autorais relativos à tradução, podendo esta explorar comercialmente, alterar, utilizar ou não, publicar, ceder e/ou licenciar a terceiros, no todo ou em parte, conforme sua necessidade ou interesse". ${ }^{6}$ A inclusão da palavra alterar nesse contrato não deixa dúvidas sobre a forma como a editora encara a tradução: uma etapa no processo de edição de obra estrangeira a ser modificada livremente pelo editor. "N ão leio a tradução publicada para não precisar discutila apenas por discutir. U ma editora somente refaria um livro que traduzi se eu entrasse na Justiça" (Wyler, tradutora). Se por um lado a editora responde pelo produto final, por outro o tradutor assina a tradução - e, tal como ressaltam os tradutores, as críticas costumam ser feitas a eles e não às editoras.

Q uando questionados a respeito de desavenças com copidesques, 87\% dos tradutores afirmaram já ter tido algum tipo de problema com esse profissional. U ma tradutora chegou a afirmar ter tido problemas em 75\% das copidescagens feitas em suas traduções. 0 utros $25 \%$ dos tradutores entrevistados afirmaram que tiveram, mas já não têm mais dificuldades com copidesques. Essas dificuldades terminaram ou porque os tradutores passaram a receber a tradução ou porque simplesmente deixaram de ler o texto publicado: "em 90\% das vezes, para evitar dissabores, não quero nem saber o que foi feito dos originaisqueentreguei" (Aguiar, tradutor); "as editorasnão enviam as revisões" (Levié, tradutora) e "é muito difícil eu chegar a abrir um livro com minhas traduções, 0 que certamente deve me poupar muitos dissabores" (Flaksman, tradutor).

Já 60\% dos copidesques afirmaram nunca ter se desentendido com editores. Para $25 \%$ dos que disseram já ter tido algum desentendimento, isso ocorreu em função de "expectativas diferentes em relação ao trabalho, como por exemplo, qualidade versus prazo" (Canetti, copidesque) e "deficiência na comunicação entre as partes. Já aconteceu deo editor desejar um trabal ho com pouca intervenção, e eu ter interferido demais, ou vice-versa" (Guimarães, copidesque). Além disso, foram mencionados

60 | Tradução em Revista 
prazos mal estipulados (aliás, cada vez menores); editoras que não fazem uma boa articulação entre seus prestadores de serviço e, depois, atribuem asfal hassó a estes; tradutoresquenão se responsabilizam pela qualidadedeseu texto [...], e aí o copi quese vire para transformar aquilo em português; ou copis negligentes, que deixam o trabalho pesado para o revisor. (R odrigues, copidesque)

Esses três exemplos evidenciam a necessidade de um bom canal de comunicação entre os profissionais envolvidosno processo editorial. A copidesque Thelma Guimarães cita o que considera ser uma boa iniciativa para o aperfeiçoamento da comunicação entre as partes, tomada por uma grande editora de São Paulo: "U ma pessoa do RH da própria editora tel efona para o prestador de serviços externo e pede que ele avalie o desempenho do funcionário interno com quem tem contato. São discutidos pontos como fluidez da comunicação, a transparência quanto a prazos e remuneração, dentre outros".

Ao contrário dos tradutores, $76 \%$ dos copidesques afirmaram nunca ter tido problemas com tradutores. Tal como mencionamos no início do trabalho, pela maneira como a pergunta foi formulada muitos copidesques tiveram a impressão errônea de que nos referíamos a um "encontro físico": "como não costuma haver contato entre o tradutor e [o copidesque], seria difícil haver um confronto. Já tive uma experiência que foi exatamente o contrário, o tradutor ficou muito agradecido porque sal tos e erros da tradução del e foram descobertos e corrigidos" (Silva, copidesque).

Algumas queixas de copidesques foram dirigidas a outros profissionais envolvidos no processo editorial, o que demonstra que nem sempre há harmonia nesse processo, mesmo quando não se está falando da relação tradutorcopidesque. I sabel Rodrigues, citada acima, referiu-se a "copisnegligentes, que deixam o trabalho pesado para o revisor" e AndréTelles chamou atenção para um outro tipo de relação, "[essa], terrível, do copidesque com a figura do revisor técnico [...], que, às vezes, invocando autoridade técnica, impõe[m] e consolida[m] traduções infelizes".

\section{C onclusões}

Tenho sempre procurado dialogar com os revisores e o resultado disso tem sido duplamente satisfatório: no que me diz respeito, ele me garante o conforto de uma responsabilidade compartilhada; no que respeita ao livro em si, ele instaura uma instância de discussão que permite conciliar e, eventualmente, harmonizar, interesses editoriais com interpretações não coincidentes com tais interesses. (João Azenha, tradutor) 
Seria o texto final do processo de edição de obra estrangeira um "produto de criação coletiva" e a tradução "um trabalho a ser continuado e modificado em etapas subseqüentes" (ver Linz, 2004: 27)? C aberia ao tradutor parar de se queixar da copidescagem e assumir seu lugar como apenas "um dos colaboradores na edição de um livro" (ibid)? 0 u caberia ao tradutor deixar de lado 0 conformismo e lutar contra as atuais políticas das editoras a fim de defender sua escrita tradutora e exigir o direito à revisão da copidescagem?

Pelo que vimos, no tocanteà copidescagem de seus textos, a expectativa da maior parte dos tradutores é a de que o copidesque só intervenha quando há ocorrência de erros binários. Q uando o copidesque intervém em outras circunstâncias, a tendência do tradutor é achar que ele quer "mostrar serviço". Segundo o Eurologos, site que oferece serviços de tradução, entre tradutores e copidesques haveria um "implacável ciúme do rival"; por esse motivo, "o [copidesque] do cliente [...] não deve se deixar levar por uma inútil competição estilística ou um confronto de personalidades", devendo "resistir ao impulso natural de querer reescrever o texto, sabendo que nada é mais subjetivo que o julgamento de uma linha bem traduzida" (grifos nossos). A tendência dos tradutores, de fato, é encarar a copidescagem como uma etapa secundária relativamente à tradução. E, ao colocá-la em uma posição secundária, os tradutores passam a se ver como donos absolutos do texto. 0 s tradutores que se afinam com a visão mais recente dos estudos da tradução, a pós-estruturalista, caem em contradição justamente por exigi rem da copidescagem uma postura neutra e, ao mesmo tempo, ressaltarem a inevitabilidade de sua própria intervenção na obra que traduzem.

Ao nosso ver, caberia aos tradutores a conscientização de que, se na relação autor-tradutor não há como o tradutor se auto-anular, tampouco na relação tradutor-copidesque há como o copidesque se auto-anular - isso seria, tal como vimos, virtualmente impossível. Ao exigir essa neutralidade do copidesque, o tradutor - como na visão universalista da relação tradutor-autor contra a qual as teorias pós-estruturalistas tanto vêm se opondo - passa a assumir a posição de "Autor" com letra maiúscula, colocando-seem posição superior à do copidesqueao não tomálo como um profissional que, influenciado por sua própria visão de mundo e cultura, fará escolhas diferentes das suas. 0 cerne do problema não está nas idiossincrasias do copidesque, mas na impossibilidade de o tradutor questionar as modificações que a seu ver são incorretas.

A nossa defesa dessa postura diferente a ser adotada pelo tradutor no tocante ao copidesque não significa, entretanto, que consideramos infundadas as constantes queixas dos tradutores no quetangeà copidescagem. M uito pelo 
contrário; como vimos, embora os tradutores tenham ressaltado a relevância da copidescagem, o número de intervenções consideradas prescindíveis e inadequadas foi muito superior ao número de intervenções consideradas adequadas e até mesmo imprescindíveis. M esmo que essas queixas possam ter se baseado na exigência de neutralidade do copidesque, são inúmeros os exemplos de intervenções de fato incorretas. $E$ é justamente por sabermos que os textos podem receber interpretações distintas que defendemos a idéia de o texto voltar para o tradutor, já que é ele o responsável pelas interpretações feitas, inclusive porque é el e quem assina a tradução. Assim sendo, tal como sugerido por vários tradutores, parecenos que o ideal seria que, uma vez concluída a copidescagem ou revisão, o texto sempre retornasse ao tradutor.

Sou daqueles queacreditam querevisor etradutor devem compor uma dupla que se complementa e não um par de tradutores que competem. Tanto na revisão lingüística, aquela que trata do estilo na língua-alvo, quanto na revisão técnica da tradução técnica [...] o uso pelo revisor do recurso dos "comentários" oferecido pelo Word possibilita um "diálogo" interativo entrerevisor e tradutor, em benefício do produto final. (H aroldo N etto, 2003: 141)

Todos os relatos de experiências nas quais houve esse retorno foram tão positivos que as queixas contra copidesques, se não cessaram, diminuíram acentuadamente. Supomos que, mesmo sem receber uma remuneração adicional, os tradutores certamente estariam dispostos a rever a copidescagem a fim de evitar alterações que considerem incorretas ou mesmo de serem convencidos do contrário. Supomos também que o copidesque, se instituída a prática de retorno do texto copidescado ao tradutor, passaria a interferir menos. Se algumas editoras já adotaram a prática de enviar a copidescagem do texto-meta aos tradutores, apesar dos prazos apertados para publicação de obra estrangeira, as demais podem seguir o exemplo.

$\mathrm{N}$ ão obstante, além de mencionar os prazos apertados, outra prática comum das editoras é recorrer à seguinte justificativa: "modificações sem consulta ao tradutor só são feitas quando se tem muita certeza do que será alterado e acredita-se que o tradutor concordaria" (C osta apud Linz, 2004: 22). É difícil acreditar que al guém possa saber exatamente com quais al terações el e estaria de acordo. Tal como vimos, uma alteração, por menor que seja, pode eliminar um termo que custou ao tradutor horas, dias ou até semanas de pesquisa. Além do mais, os próprios copidesques e revisores estão sujeitos a cometer, ou a deixar passar, erros. Portanto parece-nos justo que o texto volte ao tradutor após a copidescagem, ou a revisão final. 0 resultado de um trabal ho conjunto 
será, sem dúvida al guma, um texto de melhor qualidade. Além disso, essa troca de idéias contribui para o aperfeiçoamento profissional do copidesque e do tradutor:

\begin{abstract}
em uma das editoras trabalhei in-house durante dois anos. Fazia as traduções lá e as médicas revisavam lá mesmo, então nosso contato era direto e diário. Era muito interessante porque a revisão era comentada comigo posteriormente, então eu podia ter uma idéia de pontos a melhorar, termos corretos a usar, etc. Acho que esta seria a situação ideal de trabal ho de tradutores e revisores - contato estreito, diálogo, aprendizado constante." ( $N$ ascimento, tradutora)
\end{abstract}

$\mathrm{Na}$ condição de clientes e gerentes do processo editorial, os editores decidem como el eserá conduzido e, portanto, exercem um papel fundamental não só na relação entre autores-tradutores, como também na relação entre tradutores-copidesques. Se os tradutores quiserem mudar a atual política das editoras, terão de convencer os editores de que, no final, serão eles os grandes beneficiados ao permitirem o retorno da copidescagem ao tradutor, pois sem dúvida alguma estarão não só harmonizando relações de trabalho potencialmente problemáticas, como colocando no mercado um produto de qualidade superior.

\footnotetext{
${ }^{1}$ Este artigo foi concebido originalmente como monografia de conclusão do Curso de Especialização em Tradução da PU C-Rio (2005), sob a orientação da professora M aria Paula Frota.

${ }^{2} \mathrm{Q}$ uando citarmos 0 fragmento de uma resposta ao questionário que enviamos a tradutores e copidesques, apresentaremos ao final o sobrenome do entrevistado e sua profissão. Se o fragmento citado for muito pequeno não daremos o nome do autor, para que a leitura seja mais fluida.

${ }^{3}$ Apesar de o tradutor ter mencionado o nome da editora, pareceu-nos melhor não mencioná-la, já que ele afirma ter de recorrer ao uso de pseudônimo a fim de trabal har para ela.

${ }^{4}$ CAJUEIRO , D aniele. D epoimento no Painel de M ercado oferecido aos al unos da Especialização em Tradução da PU C-Rio, em outubro de 2004.

${ }^{5}$ LEITÃO, Silvia. D epoimento no Painel de M ercado oferecido aos alunos da Especialização em Tradução da PU C-Rio, em outubro de 2004.

${ }^{6}$ Trecho de "Instrumento particular de cessão de direitos autorais de tradução" da Editora Bertrand Brasil Ltda.
} 


\section{Referências bibliográficas}

AN T U N ES, M aria Alice G . (2004) "Autoria e tradução: uma análise do romanceautotraduzido Viva o Povo Brasileiro/An InvincibleM emory". Tradução em Revista 1, 101-115.

ARRO JO, Rosemary (2002 [1986]) O ficina de tradução: a teoria na prática. São Paulo: Ática.

(2003) "A relação exemplar entre autor e revisor (e outros trabal hadores textuais semelhantes) e o mito de Babel: alguns comentários sobre H istória do cerco de Lisboa, de José Saramago". D.E.L.T.A. 19, 193-207. BARRO SO, Ivo (org.) (2003) "N ota do organizador". M O U RA, A. S. À margem das traduções. São Paulo: Arx.

(1995) "Range Rede entrevista Ivo Barroso". Range Rede. Revista de Literatura (1) 1, 25-39.

BEN ED ETTI, IvoneC \& \& SO BRAL, Adail (orgs.) (2003) Conversascom tradutores balanços e perspectivas da tradução. São Paulo: Parábola Editorial.

BRIT TO, Paulo H. (2003) "Paulo H enriques Britto". I. C. Benedetti \& A. Sobral (orgs.) Conversas com tradutores: balanços e perspectivas da tradução, 89-98. São Paulo: Parábola Editorial.

FISH , Stanley (1993) "Como reconhecer um poema ao vêlo". Trad. de Sonia M oreira. paLavra 1, 156-165.

FRAN ÇA, Lúcia H elena (2003) "Lúcia H elena França”. I. C. Benedetti \& A. Sobral (orgs.) Conversas com tradutores: balanços e perspectivas da tradução, 103-110. São Paulo: Parábola Editorial.

FROTA, M aria Paula (2000) A singularidade na escrita tradutora: linguagem e subjetividadenos estudos da tradução, na lingüística ena psicanálise. C ampinas e São Paulo: Pontes e Fapesp.

(2004a) "Tradução e Ética". Trabalho apresentado no III Congresso Ibero-Americano de Tradução e Interpretação (CIATI). Enviado para publicação nos anais.

(2004b) "Erros e lapsos de tradução: um tema para o ensino". TrabaIho enviado para publicação nos $C$ adernos deTradução.

(2004c) "Traduzir é mesmo manipular?" Trabal ho apresentado no IX Encontro $\mathrm{N}$ acional de Tradutores e III Encontro Internacional de Tradutores. Enviado para publicação nos anais.

G O N Ç ALVES, M aria Stela (2003) "M aria Stela Gonçalves". I. C. Benedetti $\&$ A. Sobral (orgs.) Conversas com tradutores: balanços e perspectivas da tradução, 111-117. São Paulo: Parábola Editorial. 
ILG , Clarissa de Paula (2004) "O Rubaiyat... de quem? Aspectos da leitura no processo de tradução". Tradução em Revista, 1, 41-74.

KO GUT, Patrícia (2005) “D iretor é 'deportado' de 'América'”. 0 G lobo, 13 de abril.

KU N D ERA, M ilan (1996) "A tradução como arte da fidelidade". Folha deSão Paulo, 05 de maio.

LIN Z, M aryanne B. (2004) "A tradução no processo de edição do livro". M onografia inédita apresentada ao curso de Especialização em Tradução Inglês-Português da PU C -Rio.

M ARTIN S, H elena (2004) "Três caminhos na filosofia da linguagem". F. M ussalim \& A. C. Bentes (orgs.) Introdução à lingüística: fundamentos epistemológi cos v. 3. São Paulo: Cortez.

M ELLO, Simone de (2004) "Tradutores são os leitores mais precisos". h http:/ Lwww.dw-world.de/dw/article/0, 1226106,00.html. Acesso em março de 2005.

M O U N IN , G eorges (1975 [1963]) O sproblemasteóricos da tradução. Trad. de H. de L. D antas. São Paulo: Cultrix.

M O URA, Agenor S. de (2003) À margem das traduções. I. Barroso (org.) São Paulo: Arx.

N ETTO, H aroldo (2003) "H aroldo N etto". I. C. Benedetti \& A. Sobral (orgs.) C onversas com tradutores balançose perspectivas da tradução, 133143. São Paulo: Parábola Editorial.

"Regras para profissionais revisores". Gestão da Qualidade Total Eurologos. www.eurologos.be/htm/Pages/pagellbr.asp . Acesso em fevereiro de 2005.

RÓ N Al, Paulo (1987 [1952]) Escola detradutores. Rio deJaneiro: N ova Fronteira.

RO SA, João G uimarães (2003) Correspondência com seu tradutor italiano Edoardo Bizzarri. Rio de Janeiro: N ova Fronteira.

SAN TAN A, Vanete D utra (2002) "O tradutor como autor: transformação e sobre-vida do 'original'". Sínteses 7, 291-296.

SITE DE TRADU ÇÃO - trad-prt@yahoogrupos.com.br. Acesso em março de 2005.

W YLER, Lia (2003) "Lia Wyler". I. C. Benedetti \& A. Sobral (orgs.) Conversas com tradutores balanços e perspectivas da tradução, 191-200. São Paulo: Parábola Editorial. 


\section{ANEXO}

Relação de tradutores e copidesques que responderam ao questionário em março e abril de 2005:

\begin{tabular}{|l|l|}
\hline TRADUT O RES & CO PIDESQ UES \\
\hline AGUIAR, Renato & BELLIN ELLO, Sergio \\
\hline AZEN H A, João & CAN ETTI, Gypsi \\
\hline BARN I, Roberta & GUIM ARÃES, Thelma \\
\hline BO RTEN, Erik & KOURY, Lucia \\
\hline BRITTO, Paulo H enriques & GERH ARDT, M ichele \\
\hline FALCK, Celina & M ELLO, H ugo \\
\hline FLAK SM AN, Sérgio & RO CH A, Teresa da \\
\hline GRILLO, M arcio & RO GRIGUES, Isabel \\
\hline LEVIÉ, Renné & SAN T O S, Fátima \\
\hline M OREIRA, Sonia & SEN N A, Janaína \\
\hline M OTTA, Regina & SILVA, Sofia Souza \\
\hline N ASCIM ENTO, M aria Inês & TELLES, André \\
\hline Q UENTAL, Raffaella & VILLELA, M aria Angela \\
\hline ROSAS, M arta & \\
\hline SO BRAL, Adail & \\
\hline WYLER, Lia & \\
\hline
\end{tabular}

